\title{
Kathmandu Valley
}

\section{Environment Outlook}
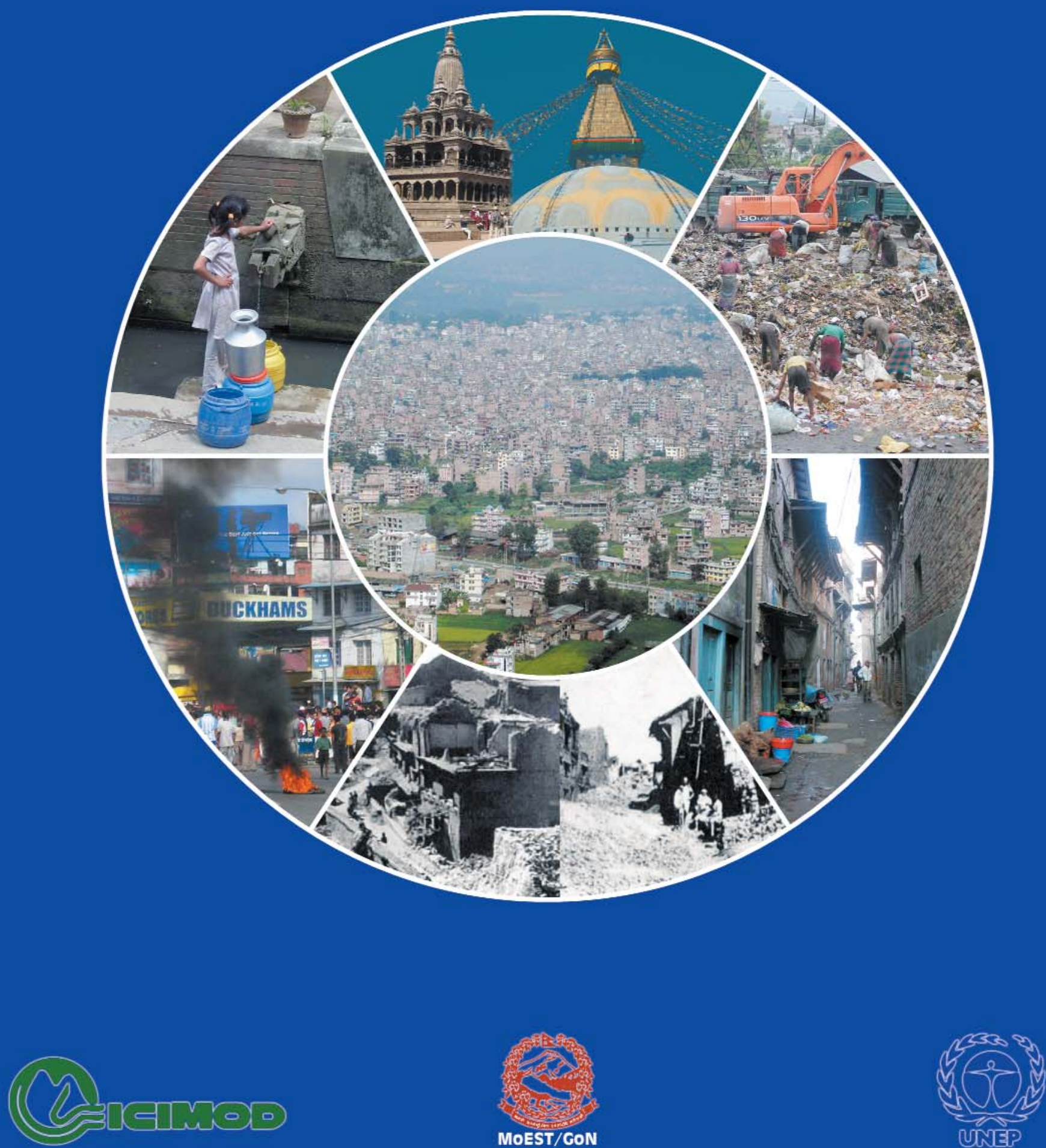


\section{About the Organisations}

\section{International Centre for Integrated Mountain Development}

The International Centre for Integrated Mountain Development (ICIMOD) is an independent 'Mountain Learning and Knowledge Centre' serving the eight countries of the Hindu Kush-Himalayas - Afghanistan, Bangladesh, Bhutan, China, India, Myanmar, Nepal, and Pakistan - and the global mountain community. Founded in 1983, ICIMOD is based in Kathmandu, Nepal, and brings together a partnership of regional member countries, partner institutions, and donors with a commitment for development action to secure a better future for the people and environment of the extended Himalayan region. ICIMOD's activities are supported by its core programme donors: the governments of Austria, Denmark, Germany, Netherlands, Norway, Switzerland, and its regional member countries, along with over thirty project co-financing donors. The primary objective of the Centre is to promote the development of an economically and environmentally sound mountain ecosystem and to improve the living standards of mountain populations.

\section{United Nations Environment Programme}

Established in 1972 and based in Nairobi, Kenya, the United Nations Environment Programme (UNEP) is the voice for the environment within the United Nations system. The Executive Director is Achim Steiner.

UNEP's mission is to provide leadership and encourage partnership in caring for the environment by inspiring, informing, and enabling nations and peoples to improve their quality of life without compromising that of future generations. Acting as a catalyst, advocate, educator and facilitator to promote the wise use and sustainable development of the global environment, UNEP works with numerous partners within the United Nations, as well as with national governments, international and non-governmental organisations, the private sector and civil society. UNEP assesses global, regional and national environmental conditions and trends; develops international and national environmental instruments; helps to strengthen institutions for the wise management of the environment; facilitates the transfer of knowledge and technology for sustainable development, and encourages new partnerships and mind-sets within civil society and the private sector.

To ensure its global effectiveness, UNEP has six regional offices: in Africa; West Asia; Asia and the Pacific; North America; Latin America and the Caribbean; and Europe. UNEP can be reached at www.unep.org

\section{Ministry of Environment, Science, and Technology}

The Ministry of Environment, Science and Technology (MoEST) was established in 2005, when the environment functions of the previous Ministry of Population and Environment (MoPE) were transferred to the then Ministry of Science and Technology. The Ministry of Population and Environment had been created in 1995, building on the previous Ministry of Forest and Environment, the first environment ministry in Nepal set up in 1991.

The main objectives of MoEST are to promote environmentally sustainable economic development of the country, promote a natural and cultural and environment, to protect life support systems, identify new technologies through the development and promotion of research activities in the field of environment, science and technology, contribute to achieving national objectives related to poverty alleviation by developing appropriate and new technologies through research, develop and promote traditional indigenous technologies, and encourage intellectual groups working in the field of environment, science, and technology by creating appropriate opportunities.

The Ministry works through three divisions - Environment, Science and Information Technology Promotion; Planning Evaluation; and Administration - and one Department (Metrology and Hydrology). Other important organs of the Ministry include the Nepal Institute for Science and Technology, the High Level Commission for Information Technology, and the Alternative Energy Promotion Development Board. The Ministry is also the focal point for various multilateral international conventions. During the short period since its establishment, the Ministry has been successful in making public some important policies and standards related to environment, science and technology.

The Ministry can be reached through its website-www.moest.gov.np and email-info@moest.gov.np. 
Kathmandu Valley Environment Outlook 


\section{Copyright $\odot 2007$}

International Centre for Integrated Mountain Development (ICIMOD)

All rights reserved

\section{Published by the}

International Centre for Integrated Mountain Development

G.P.O. Box 3226

Kathmandu, Nepal

\section{ISBN 9789291150199}

9789291150205 (electronic)

\section{Editorial Team}

Greta Rana (Consultant Editor)

A. Beatrice Murray (Senior Editor)

Dharma R. Maharjan (Technical Support and Layout Design)

Asha K. Thaku (Maps and Illustrations)

\section{Cover photo credits}

Centre - B.B. Pradhan; Outside clockwise from top - P. Dangol; ENPHO; P. Dangol; B.K. Piya; ENPHO; ENPHO

\section{Printed and bound in Nepal by}

Hill Side Press $(P)$ Ltd.

Kathmandu

\section{Reproduction}

This publication may be reproduced in whole or in part and in any form for educational or non-profit purposes without special permission from the copyright holder, provided acknowledgement of the source is made. ICIMOD would appreciate receiving a copy of any publication that uses this publication as a source.

No use of this publication may be made for resale or for any other commercial purpose whatsoever without prior permission in writing from ICIMOD.

\section{Note}

The views and interpretations in this publication are those of the author(s). They are not attributable to ICIMOD and do not imply the expression of any opinion concerning the legal status of any country, territory, city or area of its authorities, or concerning the delimitation of its frontiers or boundaries, or the endorsement of any product.

The affiliation and professional positions of the participants were those current at the time the study was conducted. 


\section{Kathmandu Valley Environment Outlook}

\section{The Study Team}

ICIMOD

Bidya Banmali Pradhan

Basanta Raj Shrestha

MoEST

Khum Raj Punjali

Chhewang N. Lama (Sherpa)
Consultants

Amar Bdr. Manandhar (Lead)

Kishore Thapa

Bandana Pradhan

Bhushan Tuladhar

Drona Ghimire

Gyani Raja Chitrakar

International Centre for Integrated Mountain Development (ICIMOD)

Ministry of Environment, Science and Technology (MoEST)

and

United Nations Environment Programme (UNEP) 

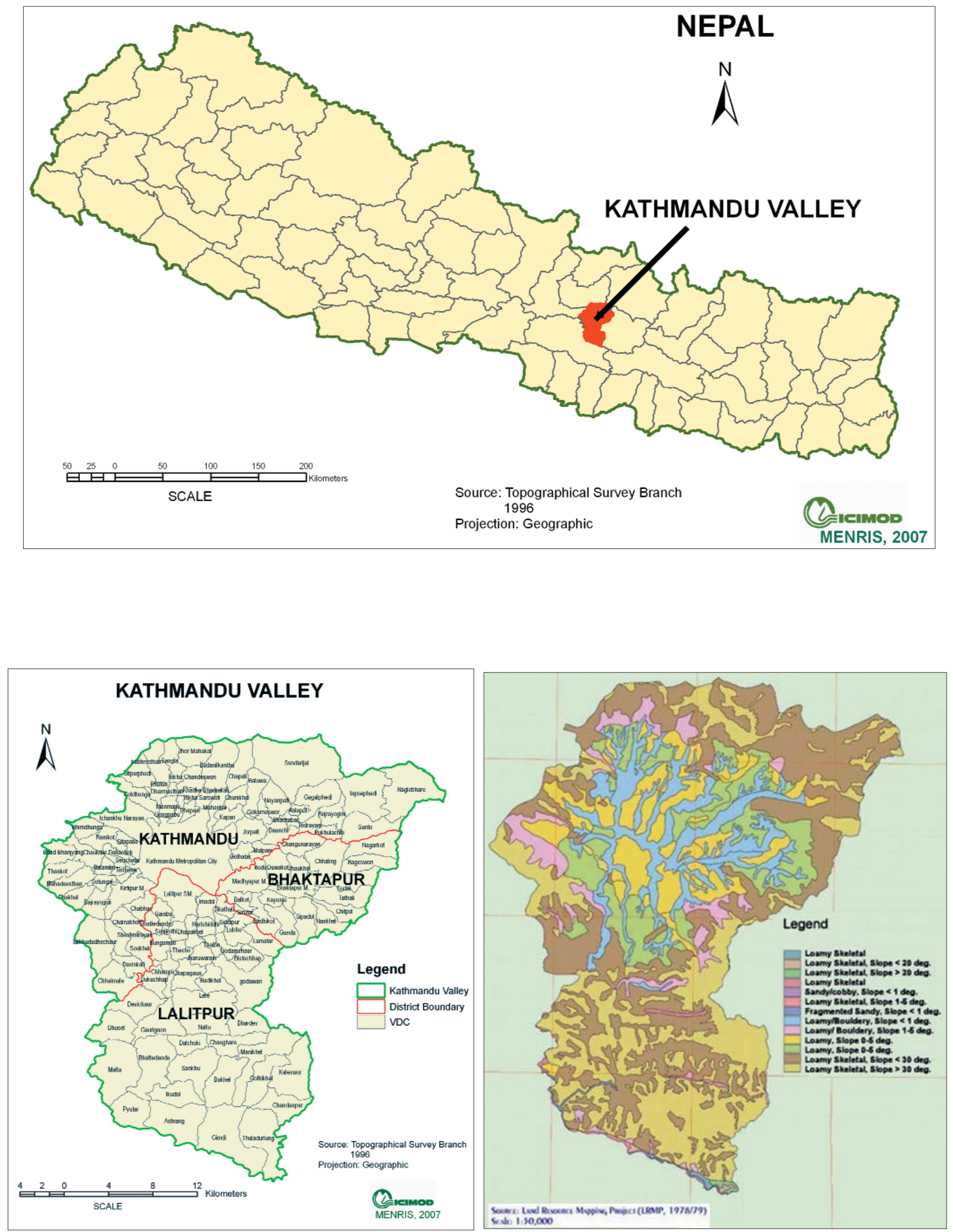


\section{Contents}

Foreword ICIMOD

Foreword UNEP

Foreword MoEST

Acknowledgements

Executive Summary

Acronyms and Abbreviations

\section{SECTION 1: BACKGROUND}

\section{Chapter 1: Introduction}

History of the Kathmandu Valley 3

Physical and Political Features 4

Human Settlement 4

Traditional Water Supplies $\quad 5$

Traditional Agricultural Practices and the Housing System 6

Cultural Heritage of the Kathmandu Valley 6

Festivals Contributing to the Environment $\quad 7$

Forests and Biodiversity 9

Pull Factors 10

Chapter 2: Social and Economic Context 11

Demographic Profile 11

$\begin{array}{lr}\text { Infrastructural Services } & 13\end{array}$

$\begin{array}{ll}\text { Economic Structure } & 18\end{array}$

Institutional Framework for the Environment $\quad 21$

Section 2: Key EnVIRONMENTAL IsSues 23

$\begin{array}{ll}\text { Introduction } & 25\end{array}$

Chapter 3: Air Quality and Traffic Management 27

Drivers 27

$\begin{array}{lr}\text { Pressure } & 29 \\ \text { State } & \end{array}$

State 32

Impact $\quad 35$

$\begin{array}{ll}\text { Response } & 38\end{array}$

Chapter 4: Settlement Pattern $\quad 45$

Drivers $\quad 45$

$\begin{array}{ll}\text { Pressure } & 45\end{array}$

State $\quad 46$

Impact $\quad 48$

Response $\quad 49$

Chapter 5: Drinking Water Resources

Drivers $\quad 58$

$\begin{array}{ll}\text { Pressure } & 59\end{array}$

$\begin{array}{ll}\text { State } & 61\end{array}$

$\begin{array}{ll}\text { Impact } & 65\end{array}$

$\begin{array}{ll}\text { Response } & 67\end{array}$ 
Pressure $\quad 73$

\begin{tabular}{ll} 
State & 74 \\
\hline
\end{tabular}

\begin{tabular}{lr} 
Impact & 82 \\
\hline
\end{tabular}

Response $\quad 84$

Chapter 7: Natural Disaster Preparedness $\quad 89$

Drivers $\quad 93$

$\begin{array}{lr}\text { Pressure } & 94\end{array}$

\begin{tabular}{lr} 
State & 94 \\
\hline
\end{tabular}

$\begin{array}{lr}\text { Impact } & 99\end{array}$

$\begin{array}{lr}\text { Response } & 101\end{array}$

$\begin{array}{ll}\text { SeCtion 3: CONCLUSION } & 105\end{array}$

Chapter 8: Problems and Policy Recommendations 107

$\begin{array}{ll}\text { Problems and Recommendations for Policy and Action } & 107\end{array}$

$\begin{array}{ll}\text { Bibliography } & 113\end{array}$

$\begin{array}{ll}\text { ANNEXes } & 119\end{array}$

Annex 1: Annual Average Extreme Temperatures 121

Annex 2: The Seven World Heritage Sites of Kathmandu Valley 122

Annex 3: Industrial Location Policy in the Valley 124

Annex 4: Geological Features of Kathmandu Valley and Surroundings 125

Annex 5: List of Participants 127

\section{List of Tables}

Table 1.1: Kathmandu Valley boundary 5

Table 2.1: $\quad$ Distribution of population by district, 1991-2001 11

Table 2.2: $\quad$ Population density by district, 1981-2001 11

Table 2.3: $\quad$ Sex ratio by district, 1981-2001 11

Table 2.4: $\quad$ Urban growth and urban population growth trend, 1952/54 - 2001

Table 2.5: $\quad$ Average annual growth rates of urban and rural population, 1952/54 - 2001 12

Table 2.6: Literacy rate in the districts of Kathmandu Valley 13

Table 2.7: Poverty measurement: Kathmandu Valley vs. other urban areas and Nepal 13

Table 2.8: Road length, population influenced, and area in the districts of Kathmandu Valley 16

Table 2.9: Total road length in Kathmandu Valley category-wise 16

Table 2.10: Licensing of communications 16

Table 2.11: Total number of schools by grades and levels 17

Table 2.12: Health facilities available in Kathmandu Valley 17

Table 2.13: Proportion of households with electricity 17

Table 2.14: Sources of drinking water 18

Table 2.15: Population receiving drinking water 18

Table 2.16: Number of industries and employment 19

Table 2.17: Status of the industrial districts in the valley 19

Table 2.18: Total and economically active population 21

Table 2.19: Households by economic activity in Kathmandu Valley 21

Table 3.1: Centralisation of development in Kathmandu Valley 27

Table 3.2: Actual revenue and expenditure for FY2003/04 (2060/61) 28

Table 3.3: Population increase in Kathmandu Valley 29

Table 3.4: Comparison of emission inventories in 1993, 2001 and 2005 
Table 3.5: Vehicles registered in Bagmati Zone 31

Table 3.6: Locations of monitoring stations in Kathmandu 32

Table 3.7: Kathmandu air quality monitoring programme 32

Table 3.8: $\quad$ Health impacts of PM $_{10}$ in Kathmandu Valley in 1990

Table 3.9: Key stakeholders in air quality management 39

Table 3.10: Steps taken to improve Kathmandu's air quality 40

Table 3.11 National policies related to air quality management 43

Table 3.12 Legislation related to air quality management 44

Table 4.1: Growth of squatter settlements in Kathmandu Valley 47

Table 4.2: Vehicle registration in Nepal 49

Table 4.3: Institutions involved in settlement development 51

Table 4.4: $\quad$ Land development projects completed in Kathmandu Valley 52

Table 4.5: Major issues and interventions proposed for the planned development of Kathmandu Valley 54

Table 5.1: The Bagmati River and its tributaries: places of origin, elevation, and length 57

Table 5.2: Discharge and catchment areas of the Bagmati River 58

Table 5.3: Estimation of wastewater generation in Kathmandu Valley urban region, 2001

Table 5.4: Access to drinking water by household at district level 62

Table 5.5: Drinking water supply and demand, Kathmandu Valley cities 62

Table 5.6: Status of water supply in Kathmandu Valley 62

Table 5.7: Distribution of stone spouts by type of use 62

Table 5.8: Bacteriological water quality of different water sources, Kathmandu Valley 63

Table 5.9: $\quad$ Sewerage coverage in Kathmandu Valley 64

Table 5.10: Wastewater production 64

Table 5.11: Distribution of macro-invertebrates by SWQ class along the Bagmati River 65

Table 5.12: Diarrhoeal and worm infestation diseases 66

Table 5.13: Types of parasites in stool samples 66

Table 5.14: Health and environment indicators 67

Table 5.15: Estimated programme costs of water supply and sanitation 68

Table 5.16: Future water projects - stages 70

Table 6.1: Municipal waste generation rates in Kathmandu over the years 74

Table 6.2: $\quad$ Recent estimates of waste generation rates in five municipalities 74

Table 6.3: Waste generation in five municipalities 74

Table 6.4: Composition of municipal solid waste 75

Table 6.5: Waste generated by the industrial estates in Kathmandu Valley 78

Table 6.6: Amount and type of waste generated by selected hospitals 78

Table 6.7: Waste generation rate and amount of waste generated at selected hospitals 78

Table 6.8: Composition of municipal wastewater at selected locations 81

Table 6.9: $\quad$ Composition of effluents from Balaju and Patan industrial estates 82

Table 6.10: Summary of water quality in the Bagmati and its tributaries 83

Table 6.11: Length of sewers in five municipalities of Kathmandu 87

Table 6.12: Wastewater treatment plants in Kathmandu Valley 87

Table 7.1: Varnes classification of mass movement 93

Table 7.2 PGA value, intensity/magnitude and liquefaction potential based on earthquake models 95

Table 7.3 Estimated casualties based on different earthquake models 95

Table 7.4: Estimated number of damaged residential buildings 95

Table 7.5: Earthquakes since 1255 which have affected Kathmandu Valley 100

Table 7.6: Information about landslides occurring in Kathmandu Valley 101

\section{List of Figures}

Figure 1: Kathmandu Valley: districts, municipalities and VDCs 5

Figure 2: $\quad$ DPSIR framework and urban air quality in Kathmandu Valley 27

Figure 3: $\quad$ Sources of $\mathrm{PM}_{10}$ in Kathmandu Valley 31

Figure 4: $\quad$ Monthly average $\mathrm{PM}_{10}$ concentrations in Kathmandu 33

Figure 5: $\quad$ Reduction in annual average $\mathrm{PM}_{10}$ in Kathmandu (2003-05) 33

Figure 6: $\quad$ Monthly average $\mathrm{PM}_{10}$ and $\mathrm{PM}_{2.5}$ in Bhaktapur 34

Figure 7: $\quad \mathrm{NO}_{2}$ concentrations in Kathmandu Valley, weekly averages in 2003/04 34

Figure 8: $\quad \mathrm{SO}_{2}$ concentrations in Kathmandu Valley (Feb-March 2003) 35

Figure 9: $\quad \mathrm{NO}_{2}$ concentrations in 2003/04 and 2004/05 35 
Figure 10: Benzene concentrations in Kathmandu Valley 35

Figure 11: $\quad \mathrm{PAH}$ concentrations in Kathmandu Valley, 2003

Figure 12: Number of COPD patients in major Kathmandu hospitals 37

Figure 13: COPD patients as a percentage of total medical patients 37

Figure 14: $\quad$ Number of COPD patients admitted to major hospitals in 2002/03 (2059) 37

Figure 15: Institutional framework for air quality management in Kathmandu 42

Figure 16: Housing process in unplanned settlements (typical case of Nepal) 48

Figure 17: Housing process in planned settlements 48

Figure 18: Organisational structure of institutions involved in settlement development 51

Figure 19: Land pooling at Nayabazar 52

Figure 20: Physical improvements in land-pooling project after implementation 53

Figure 21: Land-pooling project completed in Kathmandu Valley 53

Figure 22: A view of the outer ring road 56

Figure 23: Proposed alignment of the outer ring road 56

Figure 24: The Bagmati drainage system 57

Figure 25: DPSIR framework for drinking water resources 58

Figure 26: Demand and supply of drinking water 59

Figure 27a: Land-use pattern 1986

Figure 27b: Land-use pattern 1996

Figure 28: Institutions concerned with drinking water supplies 61

Figure 29: Contamination of groundwater, Kathmandu Valley 63

Figure 30: Arsenic concentration in groundwater (pre-monsoon season), Kathmandu Valley 63

Figure 31: BOD trend of the Bagmati River 63

Figure 32: Saprobic water quality class, Bagmati River 65

Figure 33: Disinfectant methods 71

Figure 34: Institutions and their roles in solid waste management (SMW) in Kathmandu Valley 75

Figure 35: Institutions and their roles in wastewater management in Kathmandu Valley 75

Figure 36: $\mathrm{BOD}_{5}$ seasonal variations in the Bagmati River 84

Figure 37: Change in DO levels in the Bagmati River in both dry and monsoon seasons 84

Figure 38: Distribution of epicentres 89

Figure 39: Geological cross section showing MFT, MBT, MCT, and MHT 90

Figure 40: Distribution of probable rupture zone 90

Figure 41: Engineering and environmental geological map of Kathmandu Valley 91

Figure 42: Different types of landslide 93

Figure 43: Population trend 94

Figure 44: Location map of the national seismological network 97

Figure 45: Seismic hazard map of Nepal 98

Figure 46: Epicentre map of Nepal Himalaya 98

Figure 47: Liquefaction susceptibility map of Kathmandu Valley 99

Figure 48: $\quad$ Location of landslides in the Kathmandu Valley 99

Figure 49a: Bhaktapur Durbar Square before the earthquake of 1934

Figure 49b: Bhaktapur Durbar Square after the earthquake of 1934

Figure 50: Intensity map of Kathmandu Valley during the 1934 Nepal-Bihar earthquake 100

Figure 51: Organisational chart for disaster management 103

Figure 52: Flow chart showing dissemination of earthquake information and disaster management to reduce loss of life and property

\section{List of Boxes}

Box 1: Burning tyres are injurious to health 32

Box 2: Environmental improvements in Kathmandu's brick industry 38

Box 3: Project ABC 41

Box 4: Policies for long-term development of the valley 55

Box 5: Local people's awareness 67

Box 6: Different types of landslide 93

Box 7: Difference between magnitude and intensity of earthquakes 96

Box 8: Can we predict earthquakes? 102 


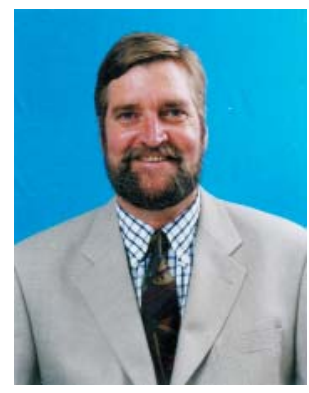

\title{
Foreword \\ Director General
}

International Centre for Integrated Mountain Development

$\mathrm{F}$

orty or fifty years ago, every pupil in the English-medium education system knew the phrase, "And the wildest dreams of Kew are the facts of Kathmandu" from one of Kipling's poems. The famous phrase gave an impression of a peaceful valley of dreams, a place of great natural and cultural beauty.

The Kathmandu valley is still a place of extraordinary natural and cultural beauty. But for those of us who were here over forty years ago, it is a valley transformed almost beyond recognition. Constantly growing traffic congestion, polluted air from vehicles and brick factories, rapidly expanding urban sprawl, streams and rivers that too often resemble sewers, piles of garbage and shortages of drinking water too often obscure the beauty beneath and beyond - the rice paddies and mustard fields still found reflecting the pagodas and high Himalaya beyond.

The present publication provides a detailed account of the status of the Kathmandu Valley environment. The report highlights the five key environmental issues of air quality, settlement, drinking water, waste management, and natural disaster preparedness, reviews their status, and recommends measures to prevent or minimise the negative impacts. The report provides direct options for management by various levels of government, civil society, the public-private sector and residents. These include improved planning and zoning, land pooling, solid waste management, rainwater harvesting, a variety of infrastructural and technical measures and vastly improved coordination and enforcement. Community mobilisation is critical to achieving these goals. With the potential for catastrophic disaster from earthquakes, many of these measures are not only important for human health, tourism development and the quality of life - but essential to the preservation of life when the inevitable earthquakes occur.

ICIMOD has been pleased to partner with the United Nations Environment Programme (UNEP) and the Ministry of Environment, Science and Technology of the Government of Nepal (MoEST) in preparing this report. It builds on previous collaborations that resulted in the Kathmandu Valley GIS Database published in 2000; the Nepal State of the Environment report, prepared by ICIMOD and published by UNEP in 2001; and the joint ADB/ICIMOD Environment Assessment of Nepal published in 2006. ICIMOD is particularly grateful to Mr. Surendra Shrestha, Regional Director, UNEP Regional Office for Asia and the Pacific for his strong support and close partnership throughout all of these efforts. We also thank Mr. Bal Krishna Prasai, Secretary, Mr. Khum Raj Punjali, Joint Secretary, and Mr. Chhewang Lama, Agricultural Officer, from MoEST and their colleagues for their contributions to the research and preparation of this report. Special thanks go to the numerous thematic experts who developed and contributed to the different chapters.

It is always easier to report on the environment than to act. We need both, and I encourage all of us to take up the concomitant action so desperately needed. Kathmandu is indeed an extraordinarily special place worth all of our effort to keep it a place of both our homes and our dreams.

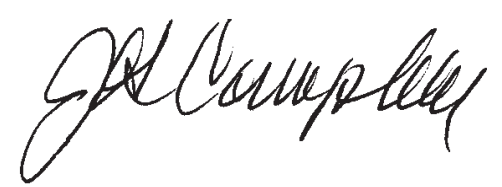

\author{
J. Gabriel Campbell \\ Director General, ICIMOD \\ January 2007
}




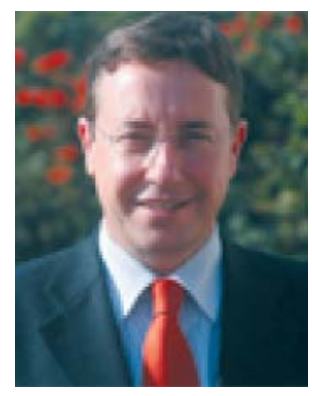

\section{Foreword \\ Executive Director \\ United Nations Environment Programme}

$\mathrm{T}$

he United Nations Environment Programme (UNEP) is mandated to regularly assess major environment developments and trends. This mandate has been practically implemented through the Global Environment Outlook (GEO) process with global, regional, sub-regional, national and even city-level assements. The GEO process is participatory, consultative and features capacity building at its core. This gives GEO assessments the necessary scientific accuracy, credibility, and authority to provide information for environmental management and policy development to a wide target audience.

The capacity building programme of the GEO process has been highlighted in the Bali Strategic Plan for Technology Support and Capacity Building, an agreed intergovernmental framework to strengthen capacity and provide technology support to developing countries and countries with economies in transition. The implementation of the Bali Strategic Plan is an important opportunity for UNEP to work with partners to strengthen national structures for environmental reporting as a basis for decision making.

Kathmandu Valley Environment Outlook is one of the outputs of UNEP's capacity building programme. The report identifies key environmental issues for Kathmandu Valley, including air quality and traffic management, unplanned settlement, degradation of water resources, waste management, and natural disaster preparedness. These issues have been analyzed by various experts, including national and city officials, scientists, academics, and civil society representatives, to determine their policy making implications. This broad-based participatory process brings national environmental issues to the attention of different stakeholders to the general public.

I hope this report will provide a sound basis for decision-making by the Government of Nepal and Kathmandu Valley Municipalities in addressing environmental issues at the policy level and in advancing the sustainable development agenda of the valley's settlements. UNEP has also been assisting the Government of Nepal to conserve the environment with collaborative activities on environmental monitoring and early warning, capacity building, and raising of environmental awareness. I would like to express my gratitude to the Government of Nepal, International Centre for Integrated Mountain Development (ICIMOD), and associated experts for this fruitful collaboration.

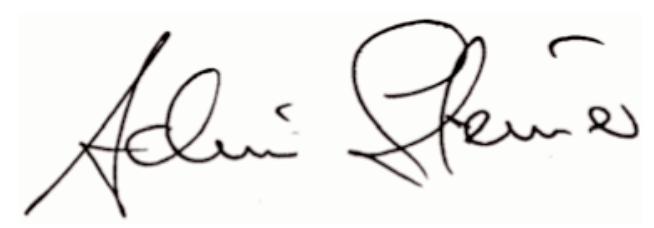

Achim Steiner

United Nations Under-Secretary General and Executive Director

United Nations Environment Programme

January 2007 


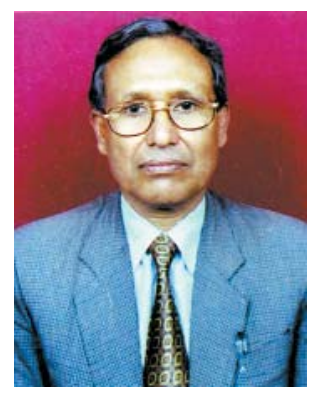

\section{Foreword}

State Minister

Ministry of Environment, Science, and Technology

$\mathrm{I}$

am delighted to be able to release this report Kathmandu Valley Environment Outlook on the occasion of the South Asia Cooperative Environment Programme's (SACEP) 10 th Governing Council Meeting 2007, in Kathmandu, Nepal.

I believe that this report has successfully focused on the emerging environmental issues of Kathmandu Valley, particularly in the fields of air pollution, water quality, urban settlement, waste management and natural disaster as well as institutional setting, including social, economic and political context of the valley. The report will serve as an instrument to reflect how, why, when and what factors influenced the transformation of the state of the environment in Kathmandu Valley and how one issue can be addressed.

Over the last decade and a half, Kathmandu Valley has experienced various environmental problems, particular the rapid growth of population, urbanisation, unplanned settlement, inadequate management of waste, increase of vehicles and emissions, traffic congestion and inadequate preservation of water bodies. The Ministry has developed a vision to address the problems across the country and to take major action towards conserving and protecting the country's environmental resources, with the aim of attaining environmentally sustainable development of the state. We have realised that appropriate capacities are essential to deal with the situation to enable a balance to be achieved among the social, economic and ecological systems for the establishment of environmentally sustainable development without creating an adverse impact on environmental services, and still providing an equal opportunity to the coming generations to have access to the environmental resources.

The Ministry has recognized that it is necessary to have partnership arrangements to deal with environmental issues through collective efforts, and has formed a strategic partnership with UNEP to implement various environmental programmes and activities in collaboration with ICIMOD. UNEP has been particularly supportive in implementing a number of programmes and projects in transboundary air pollution, including the Malè Declaration and Atmospheric Brown Cloud, the Nepal Biodiversity Year Book, promotion of environmental education and the current publication on Kathmandu Valley environment.

I strongly believe that this report will provide a significant reference document for all institutions and individuals involved in the field of environment management in the valley. The Ministry greatly acknowledges the contribution of UNEP and especially Mr. Surendra Shrestha, Regional Director, of UNEP ROAP in supporting the preparation of this report and of ICIMOD for facilitating the process especially technical input by Ms. Bidya Banmali Pradhan and Mr. Basanta Shrestha and support by the Publications Unit in bringing out the report. I also extend my thanks to those involved in the preparation of the report including our Joint Secretary, Mr. Khum Raj Punjali and Dr. Chhewang Lama, Agricultural Officer, who were also in the review committee that provided valuable inputs in shaping the report in its present form.

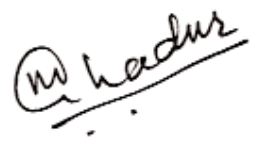

\section{Man Bahadur Biswokarma}

Honourable State Minister

Ministry of Environment, Science and Technology

January 2007 


\section{Acknowledgements}

ICIMOD would like to thank the many individuals and institutions who contributed to the preparation of the Kathmandu Valley Environment Outlook, and especially the many institutions and individuals who provided data from their own records.

Our sincere thanks go to the consultants who prepared specific chapters - Amar Manandhar of Seed Nepal (Chapters 1,2 and 4), Bhushan Tuladhar of ENPHO (Chapter 3), Bandana Pradhan (Chapter 4), Drona Ghimire (Chapter 5), Kishore Thapa (Chapter 6), and Gyani Raja Chitrakar and Birendra Piya (Chapter 7) - as well as to Bidya Banmali Pradhan and Amar Manandhar who were responsible for the overall compilation and editing of the report. The overall guidance from Basanta Shrestha and Bidya Banmali Pradhan from ICIMOD, and from Khum Raj Punjali and Chhewang Lama from the Ministry of Environment, Science and Technology, who reviewed the report, is also deeply appreciated.

This study could not have been prepared without the continuing support and encouragement of the United Nations Environment Programme, Regional Resource Centre for Asia and the Pacific in Bangkok, and especially the Regional Director of the Regional Office for Asia and the Pacific, Surendra Shrestha.

A picture speaks a thousand words, we thank the many individuals and organisations who provided photographs illustrating the report. We have tried to credit all sources and apologise if any were overlooked.

This report relied heavily on input from the staff of ICIMOD's MENRIS Division, in particular Pradeep Dangol who compiled the graphs, Govinda Joshi who compiled and/or prepared the maps, and Monica Moktan who provided administrative support and acted as rapporteur during the consultation meeting.

The extensive input from ICIMOD's Information Management, Communications and Outreach Division is gratefully acknowledged, especially A. Beatrice Murray, Senior Editor, Dharma R. Maharjan, who worked extensively to complete the layout and design on time, Asha Kaji Thaku, cartographer/artist, who helped with the figures, layout, and final proofing, and Anjesh Tuladhar who uploaded the report in Wiki form so that the group could work together more easily after the first draft consultation. The work of the consultant editor, Greta Rana, was crucial in preparing the publication. 


\section{Executive Summary}

The purpose of the 'Kathmandu Valley Environment Outlook' is to examine the current status of the environment of the Kathmandu Valley and the suburban areas of Kathmandu, Lalitpur, and Bhaktapur districts. The report analyses the emerging environmental problems and promotes specific recommendations for future action. The analysis uses UNEP'S adaptation of OECD's Driver-Pressure-State-Impact-Response (DPSIR) framework.

The two chapters in the first Section provide an overview of the historical factors and set the stage for assessing the key environmental issues in the five chapters of the second section. This analysis presents an alarming picture of a rapidly deteriorating environment. The last section summarises the analyses and identifies a number of measures for amelioration of existing problems and prevention of future deterioration.

In Chapter 1, the Kathmandu valley settlement has been traced back to 900 B.C. A rich cultural heritage has been provided through a succession of farmer kings, the development of Kathmandu as a trade entrepôt between Tibet and the states of the Indian sub continent, and the enrichment of the valley through craftsmanship and architectural monuments. Chapter 2 on social and economic factors provides a demographic profile of the subsequent urban growth and the impact of increases in transient and migrant populations. The growth of employment and education lead to an exponential rise in population and an increase in the numbers of urban poor. Infrastructure is now overloaded and poor service delivery is related to a number of issues including poor coordination.

On the topic of air quality and traffic management, Chapter 3 cites increasing affluence, rapid urbanisation, Kathmandu-centric development, and poor infrastructural capacities as key elements in the rise in air pollution. The main contributor is identified as vehicular emissions. There are increasingly negative impacts on health, especially in the form of chronic obstructive pulmonary disease (COPD). In Chapter 4, the settlement pattern is described as growing haphazardly with the tremendous increase in population. In-migration and the rapid population growth rate are driving factors leading to unprecedented land subdivision and construction in rural areas where there is insufficient infrastructure. Chapter 5 discusses the extensive deterioration in river water quality in urban areas due to excessive pollution loads. Increasing demands for drinking water place a heavy strain on insufficient supplies. Chapter 6 then describes the problems in the management of solid waste, and the negative impacts of waste and pollution on health. Earthquakes and landslides are identified as the two most prominent potential natural disasters in the Kathmandu Valley in Chapter 7. The location of the valley in a seismic zone, lack of public awareness about earthquakes, lack of adequate planning, and lack of coordination are the main factors that impact negatively on disaster preparedness. Excavation of slopes, deposition of loads on slopes, deforestation, irrigation, mining, and water leakage are the main human activities causing landslides.

In the last section, Chapter 8 provides recommendations for policies related to the five issues under analysis. These include incentives for electric vehicles and improved emission testing; effective urban planning; and air quality governance. An urban land-use and management policy for the Kathmandu Valley, along with land zoning and encouragement of infrastructural planning and construction through land-pooling projects, is seen as a sine qua non for the future of the valley. Among the many recommendations for water quality and drinking water resources are the involvement of communities in water resource planning and the biological treatment of water. Rainwater harvesting should be encouraged and water-saving practices promoted. Waste management recommendations start with the need for a basic clarification in the roles of all the agencies involved; promotion of composting, reuse, and recycling; improvement in facilities and wastewater treatment plants; and strong compliance monitoring. Finally, recommendations related to natural disaster preparedness include strengthening the existing institutions, enforcing building codes, and promoting awareness and emergency planning.

All of the recommendations are well within Nepal's means at this point in time. The report comes at an important watershed in the nation's history when many changes are being made. The report holds out the hope that with proper concerted planning and implementation of the recommendations, the Kathmandu Valley could still be a Shangri La in the middle of the Himalaya and contribute to meeting the millennium goals for the environment by 2015. 


\title{
Acronyms and Abbreviations
}

\author{
ADB \\ Asian Development Bank \\ $A Q M$ \\ air quality management \\ BKM \\ Bhaktapur Municipality \\ CBD \\ Convention on Biological Diversity \\ CBS \\ Central Bureau of Statistics \\ CEN \\ Clean Energy Nepal \\ CKV \\ Clean Kathmandu Valley \\ COPD \\ chronic obstructive pulmonary disease \\ CWTP \\ combined wastewater treatment plant \\ DDC \\ DMG \\ district development committee \\ DoTM \\ Department of Mines and Geology \\ DPSIR \\ Department of Transport Management \\ DUDBC \\ Driver-Pressure-State-Impact-Response \\ DWSS \\ ECONSAN \\ Department of Urban Development and Building Construction \\ EIA \\ EMP \\ EMS \\ ENPHO \\ EPA \\ EPC \\ EPR \\ Department of Water Supply and Sewerage \\ ecological sanitation \\ environmental impact assessment \\ environment management plan \\ environmental management system \\ ESPS \\ GPS \\ GTZ \\ $\mathrm{HCl}$ \\ Environment and Public Health Organisation \\ Environment Protection Act \\ Environment Protection Council \\ Environment Protection Regulations \\ Environment Sector Programme Support \\ global positioning system \\ German Agency for Technical Cooperation \\ ICIMOD \\ health care institution \\ IDNDR \\ International Centre for Integrated Mountain Development \\ IUCN \\ International Decade for Natural Disaster Reduction \\ JICA \\ KMC \\ KRM \\ KUDP \\ KVEO \\ KVMP \\ The World Conservation Union \\ Japan International Cooperation Agency \\ Kathmandu Metropolitan City \\ Kirtipur Municipality \\ Kathmandu Urban Development Project \\ Kathmandu Valley Environment Outlook \\ KVTDC \\ LSGA \\ Kathmandu Valley Mapping Programme \\ LSMC \\ MBT \\ MCT \\ MDG \\ MFT \\ MHPP \\ MHT \\ MoAC \\ MoEST \\ Kathmandu Valley Town Development Committee \\ Local Self-Governance Act \\ Lalitpur Sub Metropolitan City \\ Main Boundary Thrust \\ Main Central Thrust \\ Millennium Development Goals \\ Main Frontal Thrust \\ Ministry of Housing and Physical Planning \\ Main Himalayan Thrust \\ Ministry of Agriculture and Cooperatives \\ MoF \\ Ministry of Environment, Science and Technology \\ Ministry of Finance
}




$\begin{array}{ll}\text { MoFSC } & \text { Ministry of Forest and Soil Conservation } \\ \text { Mol } & \text { Ministry of Industry } \\ \text { MoICS } & \text { Ministry of Industry, Commerce and Supplies } \\ \text { MoLD } & \text { Ministry of Local Development } \\ \text { MoPE } & \text { Ministry of Population and Environment } \\ \text { MoWR } & \text { Ministry of Water Resources } \\ \text { MPPW } & \text { Ministry of Physical Planning and Works } \\ \text { MTM } & \text { Madhyapur Thimi Municipality } \\ \text { NBSM } & \text { Nepal Bureau of Standards and Metrology } \\ \text { NEPAP } & \text { Nepal Environment Policy and Action Plan } \\ \text { NESS } & \text { Nepal Environmental and Scientific Services } \\ \text { NHRC } & \text { National Health Research Council } \\ \text { NLSS } & \text { Nepal Living Standards Survey } \\ \text { NPC } & \text { National Planning Commission } \\ \text { NSC } & \text { National Seismological Centre } \\ \text { NSET } & \text { National Society for Earthquake Technology } \\ \text { NTC } & \text { Nepal Telecommunication Corporation } \\ \text { NWP } & \text { National Water Plan } \\ \text { NWRS } & \text { National Water Resources Strategy } \\ \text { NWSC } & \text { Nepal Water Supply Corporation } \\ \text { PEER } & \text { Programme for Enhancement of Emergency Response } \\ \text { SDC } & \text { Swiss Development Cooperation } \\ \text { SEED Nepal } & \text { Society for Environment and Economic Development Nepal } \\ \text { SWC } & \text { Social Welfare Council } \\ \text { SWMRMC } & \text { Solid Waste Management and Resource Mobilisation Centre } \\ \text { SWNCC } & \text { Social Welfare National Coordination Council } \\ \text { TDIC } & \text { Town Development Implementation Committee } \\ \text { UEIP } & \text { Urban Environment Improvement Project } \\ \text { UEMP } & \text { Urban Environment Management Programme } \\ \text { UNDP } & \text { United Nations Development Programme } \\ \text { UNEP } & \text { United Nations Environment Programme } \\ \text { VDC } & \text { village development committee } \\ \text { WAC } & \text { Water for Asian Cities } \\ \text { WECS } & \text { Water and Energy Commission Secretariat } \\ \text { WHO GV } & \text { World Health Organisation guideline value } \\ \text { WHO } & \text { World Health Organisation } \\ & \end{array}$

\section{Scientific and temporal measurements}

$\begin{array}{ll}\mu \mathrm{g} & \text { microgram (10-6 gram) } \\ \mu \mathrm{g} / \mathrm{m}^{3} & \text { microgram per cubic metre } \\ \text { A.D. } & \text { (Anno Domini) of the Christian era } \\ \text { B.C. } & \text { before Christ } \\ \text { B.S. } & \text { Bikram Sambat (era used in Nepal) } \\ \text { BOD } & \text { biological oxygen demand } \\ \text { CNG } & \text { compressed natural gas } \\ \text { CO } & \text { carbon monoxide } \\ \text { COD } & \text { chemical oxygen demand } \\ \text { DO } & \text { dissolved oxygen } \\ \text { HC } & \text { hydrocarbon } \\ \text { HSU } & \text { Hartridge smoke unit }\end{array}$




$\begin{array}{ll}\text { LPG } & \text { liquefied petroleum gas } \\ \text { mId } & \text { million litres per day } \\ \text { MMI } & \text { modified Mercalli intensity } \\ \text { NAAQS } & \text { national ambient air quality standards } \\ \mathrm{NO}_{2} & \text { nitrogen dioxide } \\ \mathrm{NO}_{\mathrm{x}} & \text { nitrogen oxides } \\ \mathrm{PAH} & \text { polycyclic aromatic hydrocarbon } \\ \mathrm{PM}_{2.5} & \text { particulate matter of diameter } 2.5 \text { microns or less } \\ \mathrm{PM}_{10} & \text { particulate matter of diameter } 10 \text { microns or less } \\ \mathrm{POP}_{\mathrm{S}} & \text { persistent organic pollutants } \\ \text { SWQ } & \text { saprobic water quality } \\ \text { SODIS } & \text { solar disinfection } \\ \text { SOx } & \text { sulphur oxides } \\ \text { SO } & \text { sulphur dioxide } \\ \text { TDS } & \text { total dissolved solids } \\ \text { TSP } & \text { total suspended particles } \\ \text { TSS } & \text { total suspended solids }\end{array}$

\section{Currency Equivalent}

In this report all references to rupees (Rs) are to Nepalese rupees

Currency Unit - Nepalese rupees (NRs)

$\$ 1=$ NRs 70.60

(As of 2 January 2007)

\section{Notes}

(i) The Nepalese calendar year (B.S.) runs from mid April to mid April. Unless otherwise stated, year ranges written in the form 2005/06 denote a single calendar year.

(ii) The fiscal year (FY) of the Government ends on 15 July. FY before a calendar year denotes the year in which the fiscal year ends. (For example, FY2000 begins on 16 July 1999 and ends on 15 July 2000.)

(iii) In this report, \$ refers to US dollars.

(iv) In this report, tons (t) refer to metric tons or tonnes $(1,000 \mathrm{~kg})$.

(v) Acts and Regulations are cited under the name of the ministry from which they originate. The official version of Acts and Regulations is published in the Nepal Gazette (in Nepali). Some Acts and Regulations are published by other Government agencies in English (unofficial translations). 